\title{
Deletion of Y-Allele in Autosomal STR and Role of Y-STR
}

\author{
Naresh Kumar ${ }^{1}$, Amit Chauhan $^{2 *}$, Ritika Gupta ${ }^{1}$, Aanchal Maitray ${ }^{1}$, SK Shukla ${ }^{2}$ \\ ${ }^{1}$ Forensic Science Laboratory, Home Department, Delhi, India \\ ${ }^{2}$ Amity Institute of Forensic Sciences, Amity University, Uttar Pradesh-Noida, India \\ *Corresponding author: Amit Chauhan, Amity Institute of Forensic Sciences, Amity University, Uttar \\ Pradesh-Noida, India. Tel: +91-9540067484, E-Mail: amit_chauhan777@yahoo.in
}

Received Date: 18 December, 2018; Accepted Date: 04 January, 2019; Published Date: 21 January, 2018

\begin{abstract}
Sexual assault has become a major issue of concern in all over the world. Distinct procedures are followed to prevent such crime and to punish the perpetrator as per land of law and based on the scientific evidences. DNA profiles of perpetrator/victim can help to determine the identity from the biological evidence left on the scene of occurrence. The identity of gender is also determined from the biological samples and DNA profile that is based on presence of Y allele in amelogenin in autosomal STR. Presence of $\mathrm{Y}$ chromosome provide help to determine the gender of accused (male or female). In a few of instances, it becomes challenging to identify the involvement of a male specially when there is no $\mathrm{Y}$ allele on amelogenin in autosomal STR. In this study, we used Ampf1STR identifier plus kit having 15 plus one amelogenin markers and as a resultant of it, we observed that; out of 708 DNA profiles from the population of Delhi, 2 profiles were without Y allele on the amelogen marker. Absence of Y alleles on amelogenin male samples are sometimes misinterpret as a female. In such cases, Y chromosome specific Y filer kit is used for determination of male. In such Y deleted amelogenin situations, the marker G_DYS458 is simultaneously either absent or degenerated on Y STR. It was also observed that, the use of $\mathrm{Rz}$ - PCR is the best way to determine the quantity as well as for the identification of gender prior to use of Identifier or Y filer kit for authentic opinion. Determination of quantity and gender are not affected in RT-PCR because of the deletion of Y amelogenin.
\end{abstract}

\section{Keywords}

Autosomal STR, Amelogenin, Genetic Material, Quantity, Y Chromosome

\section{Introduction}

In cases of unidentified or decomposed dead bodies, Forensic samples are sent to the forensic laboratory in form of bone pieces, piece of body parts in case of mass disaster. While in cases of sexual assault, the identity of gender is also determined from such samples and further matching thereof on the basis of DNA profiles. The examination of such samples where gender of sample is not known or in sexual assault cases where female biological material is already present is little tough. Inappropriate techniques of examination done by untrained and inexperienced scientific personals make it vulnerable to surrender before the court or defence counsel. It has been observed that there is a mixed profile of male and female in the samples of vaginal swabs or undergarments of victims in rape cases, but due to small quantity of male fraction or missing of $\mathrm{Y}$ allele on marker amelogenin, results were misinterpreted as negative case [1]. The role of $\mathrm{Y}$ chromosome is very clear in sex determination and research established. Deterioration of $\mathrm{Y}$ chromosome was started many generations ago it was as large as $\mathrm{X}$ chromosomes. The human amelogenin has two homologous alleles one on $\mathrm{X}$ and other on $\mathrm{Y}$ chromosome. The size of Amelogenin $\mathrm{X}$ and amelogenin $\mathrm{Y}$ differ in size, $\mathrm{X}$ gene size is 2872 base pair and $\mathrm{Y}$ is 3272 base pairs. Location of amelogenin on $\mathrm{X}$ is $\mathrm{Xp} 22.1-22.3$ and $\mathrm{Y}$ is Yp11 [2].

In forensic field, it is very common that experts don't perform the quantitation of DNA or using nano drop for this purpose or even $\mathrm{Y}$ filer kit is not being used in such cases. The reports are being submitted only based on the autosomal STR. Determination of gender from the samples are decided based on the amelogenin marker [3]. It is necessary to examine the samples in proper way and prepare the report of the cases with proper justification in such cases where, $\mathrm{Y}$ allele is absent or degenerated in sexual assault cases or in unidentified/ decomposed/ part of dead bodies. Female samples do not contain the Y allele that's why the absence of Y does not guarantee that sample is of female. It is correct that amelogenin must be attempted as per different multiplex different kit available, but in such cases, to specific Y profile is becomes a necessity to support the multi- 
Citation: : Kumar N, Chauhan A, Guptha R, Maitray A, Shukla SK (2019) Deletion of Y-Allele in autosomal STR and Role of Y-STR. J Forensic Sci Digit Investig 2019: 50-54.

plex autosomal STR kit [4]. The ultimate purpose of amelogenin in DNA profile is to determine the gender of an individual. It is very challenging in forensic case work [5]. The detection of amelogenin can be performed by quantitative PCR. Moreover, in mixed samples where female fraction is more than 10 times peaks of male fractions are considered very poor. Other methods for sex determination relating to $\mathrm{X}$ and $\mathrm{Y}$ found on centromeric regions or sex determining region (SRY) provided in Quantifiler duo kit can also help in determination of species. The presence of $\mathrm{Y}$ chromosome determines the sample of a male, and absence of $\mathrm{Y}$ allele on amelogenin indirectly determines gender of a female. It is observed in sexual assault cases where quantity of male part is very low due to delay and hygiene condition of victim, then it becomes more difficult to identify the $\mathrm{Y}$ on amelogenin. There are two possibilities either $\mathrm{Y}$ is not present in the sample because of being from a female or Y could not be detected due to genetic specificity of the sample. It is a fact that $\mathrm{Y}$ allele is not detected in male samples due to amelogenin Y null allele [6]. The blood samples were taken to generate the $\mathrm{Y}$ allele in such samples where quantity of Male DNA was detected through quantifiler duo kit Applied Bio systems. The duo kit is the best technique and should be first step to decide whether the sample is of a male or female irrespective of the null AMELY male DNA samples, along with quantity of DNA and inhibition the samples. Further Y STR amplification will determine the gender of the sample and may strengthen the sample is male.

\section{Material and Methods}

The samples were received in the laboratory for analysis in sexual assault cases or in murder cases. During the analysis of the total cases 708 males' samples, it was found that two males were failed to give Y alleles (AMELY) on amelogenin marker [7]. The sample were received and preserved at $4^{\circ}$ Celsius for 2 to 3 months. These samples were further analysed for DNA isolation from the vaginal swabs and underwear of victim and matched with the blood samples of accused. A 3/4 portion of vaginal swab was cut into microcentrifuge tube of $1.5 \mu$ l. The samples were added in Forensic buffer, Proteinase $\mathrm{K}$ and SDS as per the recommendation of protocol. The samples were kept for overnight for digestion of cell (female fraction). The separation of female fraction in sexual assault cases is not fool proof technique but it reduces the female part present in the samples. The samples were centrifuged next day, and supernatant was discarded. The sperms (Male fraction) were left. The samples were again added forensic buffer, Proteinase $\mathrm{K}$ and SDS and dithiothreitol to digest the spermatozoa.

\section{Real Time PCR}

PCR was performed by using Quantifiler Duo kit of applied Biosystem as per manufacture protocol. Total volume was $25 \mu \mathrm{l}$ having the reaction mix and primer and DNA sample as per protocol. Standards were used with the samples to observe the accuracy of results. These results helped us to determine the availability of human male DNA in the samples. It is reliable technique to determine the gender from forensic samples while amelogenin based technology is not fully reliable. This technique is useful in case of in prenatal diagnosis [8].

Further, all samples were diluted as per the value given by RTPCR and approximately $1 \mathrm{ng} / \mu \mathrm{l}$ DNA was used for sequencing the samples AmpF1 STR. Identifiler plus kit was used for PCR amplification (Applied Biosystem [9]. This kit contains 15 markers and one marker for sex determination namely amelogenin. Applied Biosystem Identifiler plus kit was used for PCR amplification. PCR product $1 \mu \mathrm{l}$ was mixed Hi-Di formamide 24.5 $\mu \mathrm{l}$ and $.5 \mu \mathrm{l} 600 \mathrm{LIZ}^{\mathrm{TM}}$ was used. Electrophoresis was done on the instrument Genetic Analyzer (Applied Biosystem 3500XL). Samples were applied in the instrument and detail alleles were also determined by using Gene Mapper ID-X software 1.4.

\section{Result and Discussion}

Autosomal STR kits are reliable for determination of gender from the samples based on alleles on amelogenin, but the presence of $\mathrm{Y}$ allele was not observed in all male samples. Male samples were misrepresented as female in sexual assault samples, especially where quantity of female fraction is comparatively higher than the male or due to deletion of Y allele in autosomal STR profile. Such samples often contain mixture of male and female DNA. Peaks of male alleles were very low in comparison of the female DNA in these profiles. Autosomal STR of 16 makers failed to resolve male profile in such high value of female DNA. In this type of the cases, RT-PCR quantitation play an important role for confirmation of gender (males) from the sample, as it is used to confirm the presence of male DNA in the sample. Further the role Y STR analysis, by using AmpF1STR ${ }^{R}$ Y filer PCR amplification kits is also important to confirm the male gender from the sample. In this study, absence of Y STR marker G $\urcorner$ _DYS458 showed that such samples are AMELY similar to the findings of Redd A.J Ho [10] (Figure 1 and 2).

wever there were three other samples out of these 708 samples, where G_DYS458 marker was also missing even in the presence of $\mathrm{Y}$ allele in autosomal STR profiles (Figure 3 and 4).

The presence of such male sample can be identified by the use of Quantifiler Duo kit of Applied Biosystems on RT PCR machine. If male DNA is present in quantitation of such samples, then it can further be confirmed with absolute certainty by using AmpFISTRR Y filer PCR amplification kit which can amplify $17 \mathrm{Y}$ STR loci in a single reaction tube. If there is no male DNA in RT PCR quantitation, and Y STRs are not amplified then the sample is confirmed to be a female sample. In present study, it was also observed that quantity of DNA in RT-PCR was not affected due to deletion of Y amelogenin region on Y chromosome (Figure 5).

\section{Conclusion}

Delhi is the capital of India and having more than 1.50 crore population. People have been migrated from different part of India for lively hood. Gender of DNA samples misrepresented during 
Citation: : Kumar N, Chauhan A, Guptha R, Maitray A, Shukla SK (2019) Deletion of Y-Allele in autosomal STR and Role of Y-STR. J Forensic Sci Digit Investig 2019: 50-54.
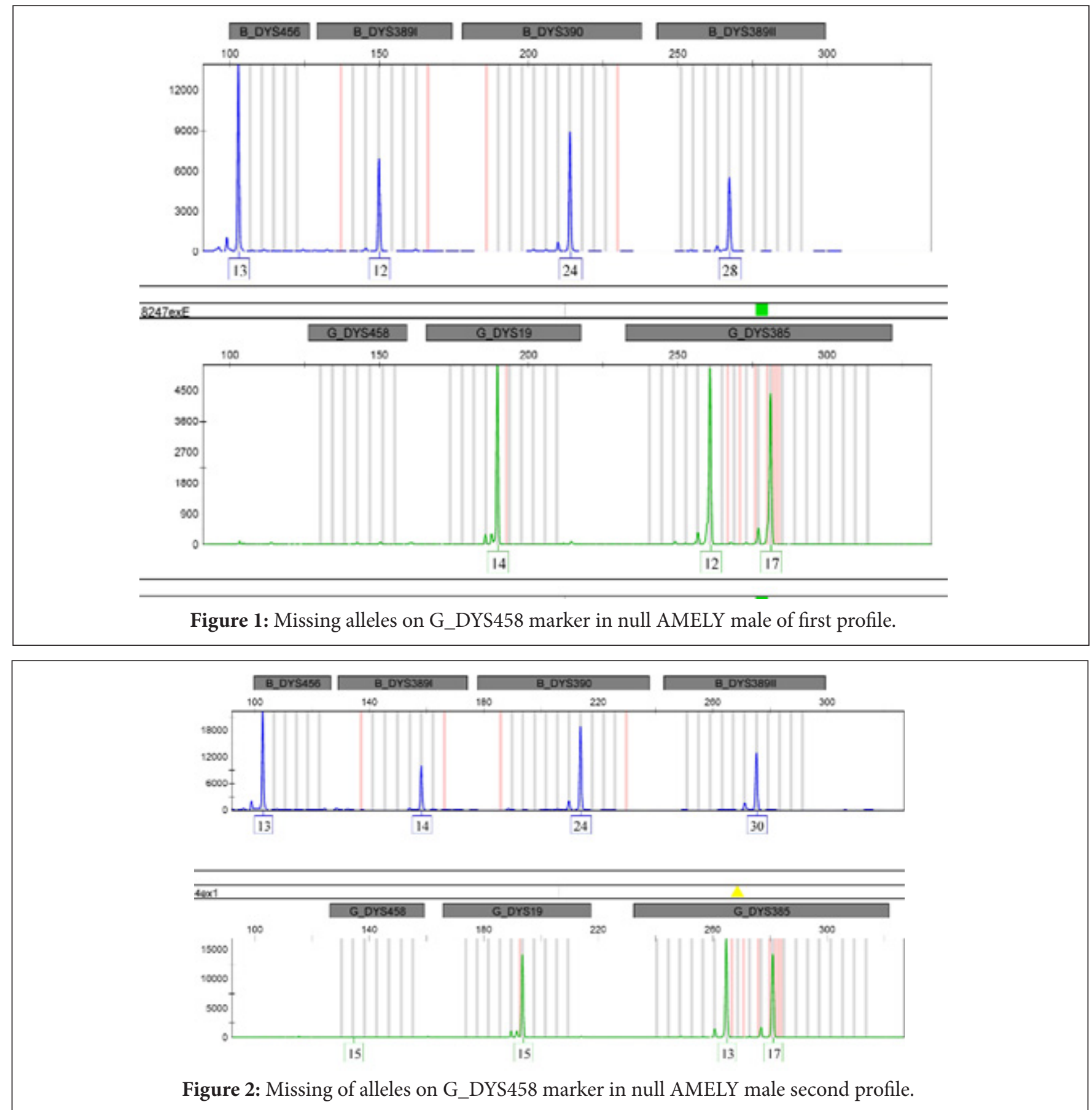

the analysis in sexual assault cases, missing identity and decomposed dead bodies. Quantifiler Duo kit play vital role to ascertain the gender of sample or to determine the availability of male in mixed sample in sexual assault cases and other cases. In this study, we took samples from the random population for missing alleles on amelogenin marker. Out of 708 samples, two males were identified without Y allele on amelogenin (0.28\%) [11]. However, there were three other cases out of these samples where no alleles were found on G_DYS458 marker within random population of Delhi (capital of India) but Y allele was confirmed on amelogenin. The result emphasizes the importance of the use of
Duo kit of of Applied Biosystem in RT-PCR for quantitation as well as for gender identification prior to the use of Identifiler or Y-filer for conclusive opinion. Precautions should be taken during the preparation of the DNA profile of a sample and concluding the result in case of missing $\mathrm{Y}$ allele in amelogenin as it can be fatal to the cases if RT-PCR is not performed. The previous studies have shown the resemblance to this study. Quantity of DNA is not affected in Real Time PCR due to deletion of Y allele on amelogenin. Moreover, less male DNA comparative to female DNA adversely affect the result and profile of the samples resulting to the negative. 
Citation: : Kumar N, Chauhan A, Guptha R, Maitray A, Shukla SK (2019) Deletion of Y-Allele in autosomal STR and Role of Y-STR. J Forensic Sci Digit Investig 2019: 50-54.

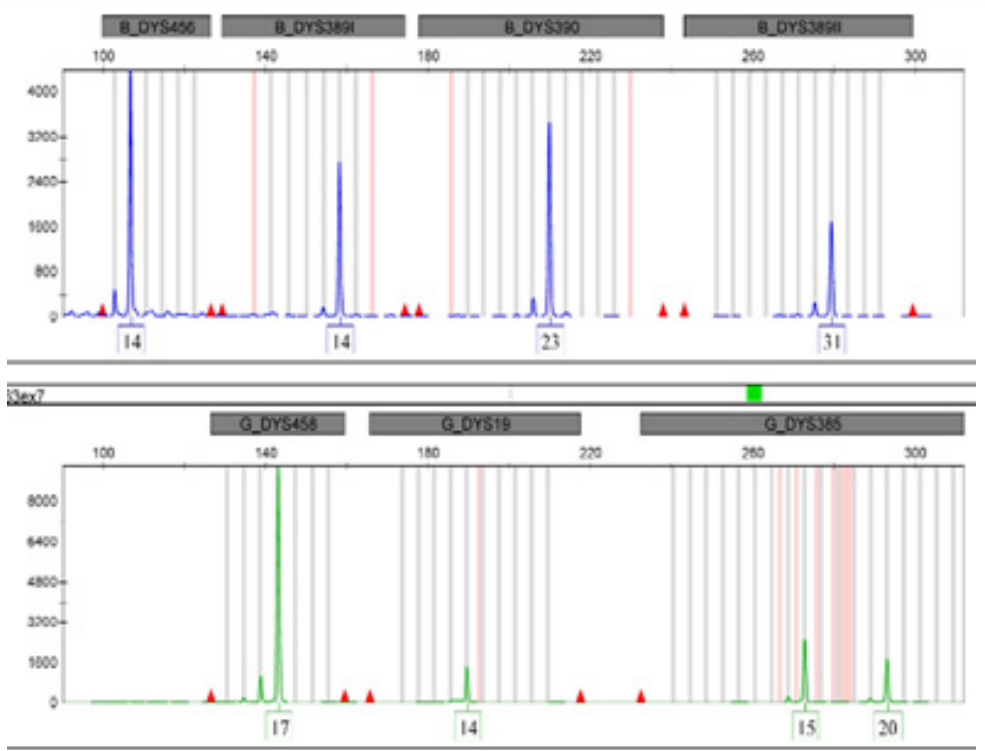

Figure 3: Normal male sample where G_DYS458 has normal allele Y-STR.

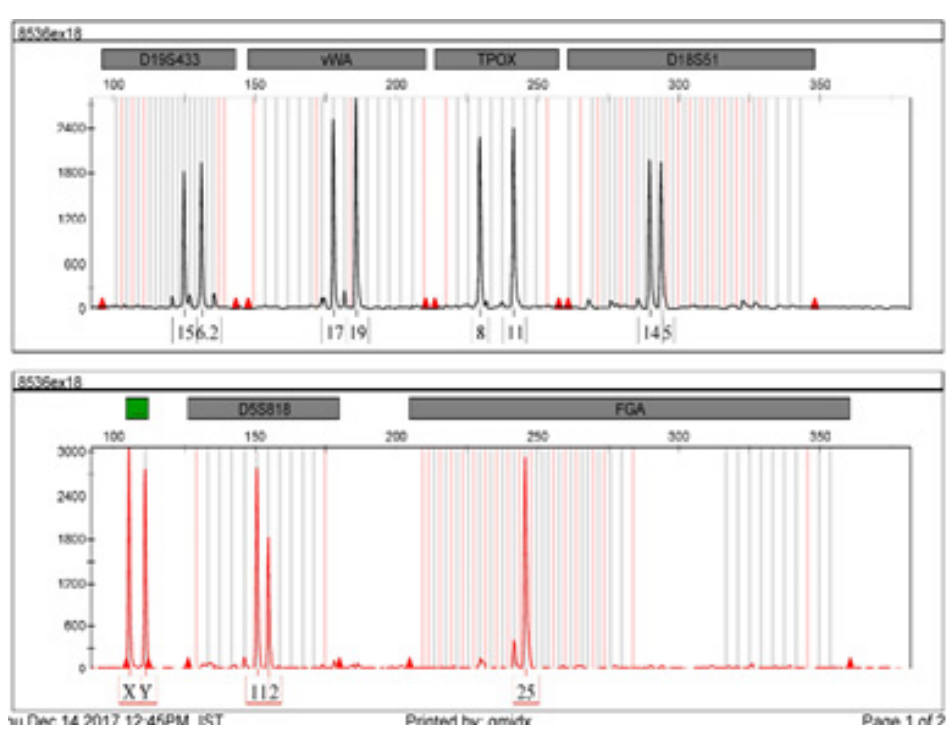

Figure 4: Normal male Y missing profile (AMELY)in autosomal STR.

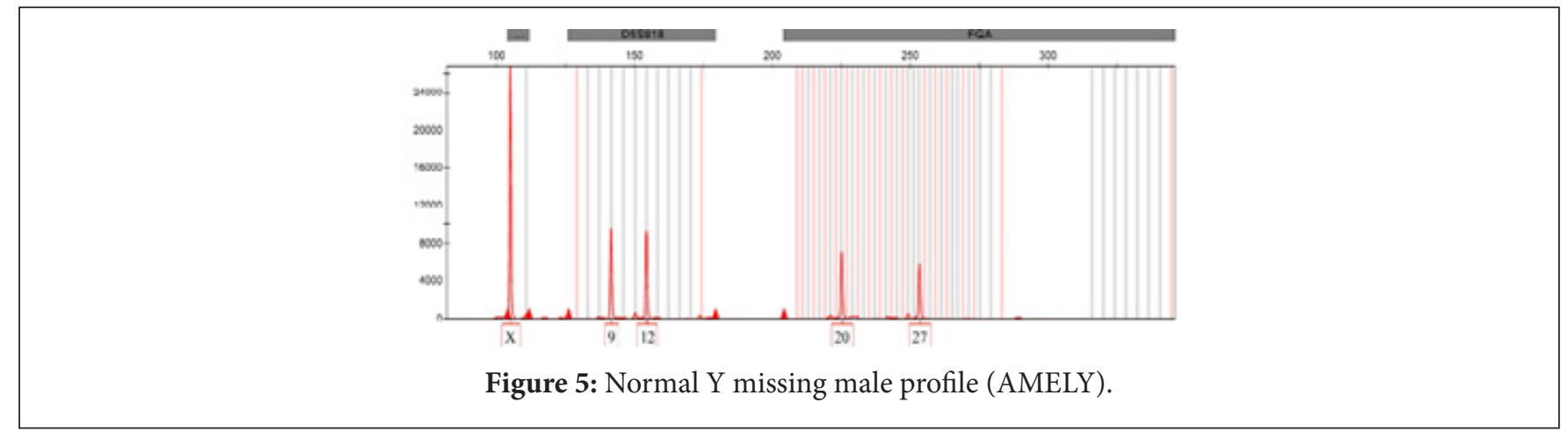


Citation: : Kumar N, Chauhan A, Guptha R, Maitray A, Shukla SK (2019) Deletion of Y-Allele in autosomal STR and Role of Y-STR. J Forensic Sci Digit Investig 2019: 50-54.

\section{References}

1. Mannucci A, Sullivan KM, Ivanov PL, Gill P (1994) Forensic application of rapid and quantitative DNA sex test by amilification of the X-Y homologous gene amelogenin. Inte J legel Med 106: 190-193.

2. Nakahori Y, Hamano K, Iwaya M, Nakagome Y (1991) Sex identification by polymerase chain reaction using $X-Y$ homologous primers. Am J med genet 39: 472-473.

3. Thangaraj K, Reddy AG, Singh L (2002) Is amelogenin gene is reliable for gender identiofication in forensic case work and prenatal diagnosis. Int j Legal med 116: 121-123.

4. Laboratory F. National DNA Index system (NDIS) Operational procedure Mannual. 1st ed.; January 31, 2013.

5. Sullivan KM, Mannucci A, Kimpton CP, Gill P (1993) A rapid and quantitative DNA sex test: Flourescence-based PCR analysis of X-Y homologous gene amelogenin. Biotechniques 15: 636-641.
6. Applied Biosystem. 2001. protocol.

7. Akane A, Shiono H, Matsubara K, Nakahori Y, Seki S, et.al. (1991) Sex identification of forensic specimenby polymerase chain reaction (PCR) two altenative methods. Forensic Sci Int 49: 81-88.

8. Thangaraj K, Reddy AG, Singh L (1998) Is amelogenin gene is reliable for gender identification in forensic case work and prenatal diagonis. Int J Legal Med 116: 121-123.

9. Biosystem a. AmpF1 Identifiler Plus Kit. user Mannual. 2001.

10. Redd AJ, Agellon AB, Kearney VA, Contreras VA, Karafet T (2002) Forensic value of 14 novel STRs on human on $Y$ chromosome. Forensic Sci Int. 130: 97-111.

11. Kashyap VK, Sahoo S, Sitalaximi T, Trivedi R. (2006) Deletion in the Y-derived amelogenin gene fagment in Indian population. BMC Med Genet. 7: 1471-2350. 